症例

家族性大腸腺腫症に対する腹腔鏡補助下大腸全摘術の 1 例

大阪大学内視鏡外科, 大阪逓信病院外科*, 関西労災病院外科**, 大阪大学第 2 外科***

\begin{tabular}{|c|c|c|c|c|c|c|c|c|c|c|c|c|c|c|}
\hline 瀧 口 & 修 & 司 & 丸 & 山 & 博 & 英** & 矢 & 野 & 浩 & 司* & 関 & 本 & 貢 & 嗣*** \\
\hline 口 & 英 & 治 & 松 & 井 & 成 & 生* & 中 & 野 & 芳 & 明* & 立 & 石 & 秀 & 郎* \\
\hline 衣 田 & 誠 & 克* & 門 & 田 & 卓 & $\pm^{*}$ & 岡 & 村 & & 純* & 大 & 橋 & 秀 & 一 \\
\hline
\end{tabular}

家族性大腸腺腫症に S 状結腸進行癌を伴った症例に対し，腹㓐鏡補助下大腸全摘術を 施行した 1 例を経験した。症例は 36 歳女性. 注腸検查にて大腸腺腫症ならびに $\mathrm{S}$ 状結腸 癌を指摘された。手術は $10 \mathrm{~mm}$ trocar を 4 本挿入し, 腹腔鏡下に大腸を腹壁および後腹 膜より剝離して全結腸を授動した。ささらに下腸間膜動脈を露出した. 下腹部正中を $9 \mathrm{~cm}$ 切開し全結腸を腹腔外へ出した後, 大網および結腸間膜を切離した. 下腸間膜動脈根部 は小切開創より直視下に郭清した. 直腸下部および肛門管も小切開創より剥離し, 大腸 を全摘した. 回腸末端にて J pouch を作製し肛門管と吻合した. 手術時間は 6 時間34分, 出血量は177gであった. 肛門機能は良好で術後 3 カ月を経過し排便回数は $3 \sim 4$ 回程度 におちついた.

真引用語：腹腔鏡補助下大腸全摘術, 家族性大腸腺腫症, 進行結腸癌

\section{緒言}

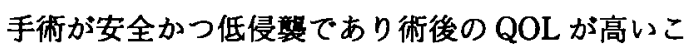
とが望まれることは言うまでもない，特に家族性大腸 腺腫症 (Familial adenomatous polyposis: FAP) で は，手術を受ける患者だけでなくその血縁者らも䍜患 者である場合があり，手術が痛みが強く，傷が大きく 恐怖を与えるものであってはならない，今回われわれ は, 大腸全摘術の minimally invasive surgery として $\mathrm{S}$ 状結腸進行癌合併 FAP に対し下腸間膜動脈 (IMA) リンパ節 (D3) 郭清を伴う腹腔鏡補助下大腸全摘術, 回腸衰肛門管吻合術を施行した 1 例を経験したので若 干の文献的考察を加え報告する.

\section{症例}

症例 : 36歳, 女性.

主訴: 下血.

家族歴：父親が直腸癌にて死亡, 同胞は直腸癌合併 FAP にて大腸全摘術施行.

既往歴：特記すべきこと無し.

現病歴: 平成 8 年 6 月下血を認め注腸検查施行し, 直腸から盲腸まで腺腫を認め, 家族性大腸腺腫症と診 断され手術目的にて当科入院.
入院時現症：身長 $163 \mathrm{~cm}$, 体重 $45 \mathrm{~kg}$. 口腔粘膜に色 素沈着想めず，その他特記すべき異常を認めず.

入院時検査所見 : Hb 8.6g/dl と貧血を認めたが，そ の他異常を認めず.

注腸検查：直腸から盲腸までポリープを多数認め $\mathrm{S}$ 状結腸に直径 $35 \mathrm{~mm}$ の Borrmann 1 型腫㽷像を認め た（図 1).

大腸内視鏡検查：直腸から盲腸まで無数の腺腫を㡈 めた. S 状結腸の腫場深達度は PM〜SS と診断した. 同部生検では Group Vであった。

上部消化管造彰/内視鏡：胃全体ならびに十二指腸 に 3 から $5 \mathrm{~mm}$ の腺腫を多数認めた. 同部生検による組 織診は Tublar adenoma ; Group III であった. 以上よ り S 状結腸進行癌合併 FAP と診断し腹腔鏡補助下大 腸全摘術, D3郭清, 回腸襄肛門管吻合術を平成 8 年 8 月 8 日施行した。

手術所見：臍下部小切開予定線上にて Hasson's methodにて trocar を挿入し気腹, $10 \mathrm{~mm}$ trocarをさ らに 3 本挿入した (図 2)，腹腔鏡下に大腸を腹壁およ び後腹膜より剝離し全結腸を授動しさらにIMA 根部 を露出した（図 3 ). 下腹部正中の trocar hole を9cm 縋切開延長し全結腸を大網を含め腹腔外へ出したの ち，大網結腸間膜を切離した，小切開創より直視下に

1997年 8 月 7 日受付 1997 年11月11日採用 
IMA 根部の郭清をし，253リンパ節をゲフリールへ提 出転移陰性を確認した。直腸下部は, 小切開創より剝 離し崡状腺より $2 \mathrm{~cm}$ 直腸を残し大腸を全摘した（図

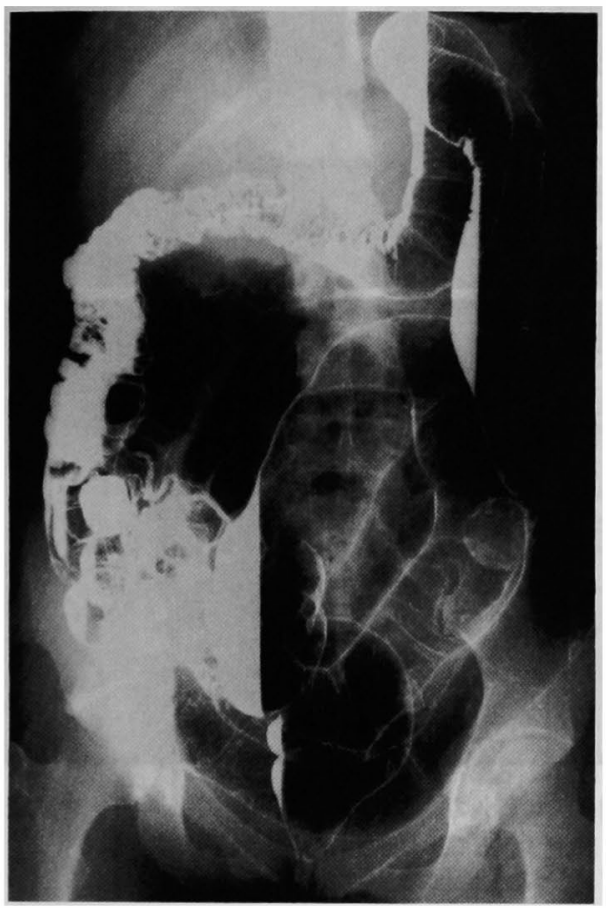

図 1 注腸造影：棈円形のバリウム透亮像を直腸から 盲腸まで100以上認め, $\mathrm{S}$ 状結腸に直腸 $35 \mathrm{~mm}$ の Borrmann 1 型腫瘍を認めた。

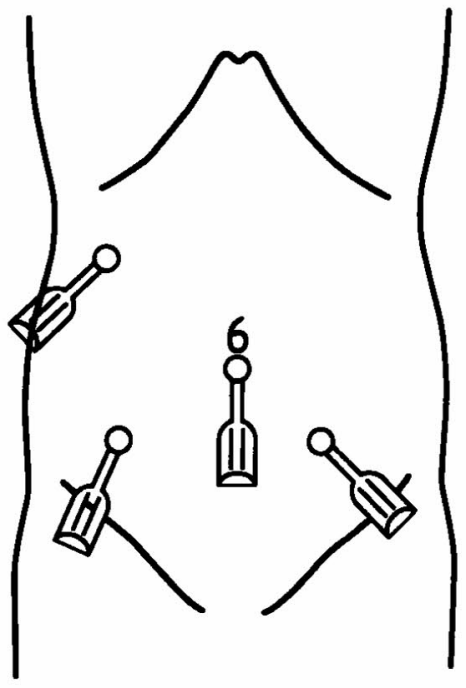

4)。回腸末端にてJ-pouch を作製し肛門管直上にて 端々に自動吻合器を用いて吻合した。手術時間は 6 時 間34分，出血量 $177 \mathrm{~g}$ であった。

病理組織学的所見：全大腸に無数の腺腫を認めた （図 5 ).S 状結腸癌は, $33 \times 38 \times 15 \mathrm{~mm}$ の Borrmann 1 型腫場で高分化腺癌, mp, ly2, v0, n1, $2(+)$, ow $(-)$, aw $(-)$, ew (-), stage IIIb, 組織学的根治 度 A であった。

術後経過：術後 2 日目に排ガスを認めた。術後経過 は良好で24日目に退院した。排便機能は良好で術後 3 カ月経過し排便回数は 1 日 $3 \sim 4$ 回程度となった。

\section{考 察}

開腹による大腸全摘術は，1950年頃から施行されて いる，その後は主に再建法に関する工夫がなされてい るのみであった。一方腹腔鏡補助下の結腸切除術は Jocobsにより1991年にはじめて報告された ${ }^{1)}$ ，大腸全 摘術に対しても腹腔鏡補助下手術は行われており欧米 ではその有効性につき prospective studyも報告され ている゙2. 本邦でも数例の報告がなされている314).

腹腔鏡助下大腸切除術はわが国でも早期癌に対し確

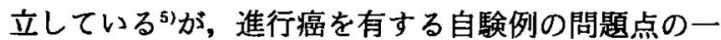
つとして郭清が十分に行えるかどうかがあげられる。 われわれの経験から鏡視下で D2までの郭清は十分可 能とし施行してきたが，自験例の S 状結腸における腫 瘍深達度では D3郭清が必要と考えられたため根治性 を椇わない樣に小切開創を通常より大きくし直視下に

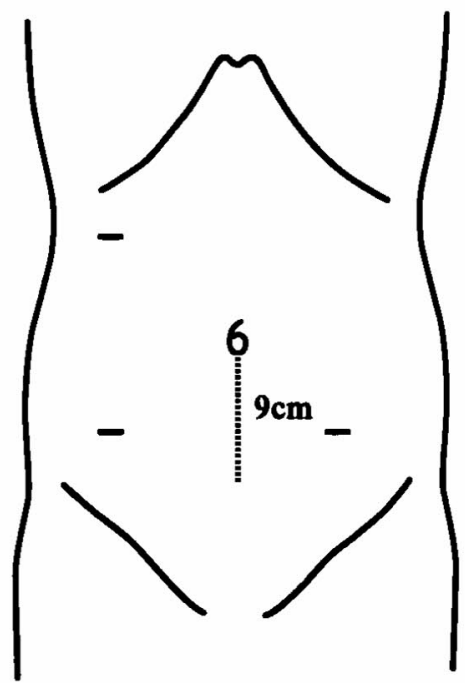

図 2 トロカール位置を左図の如くとし，右図の如く皮切を下腹部正中に $9 \mathrm{~cm}$ 緃切開 す. 

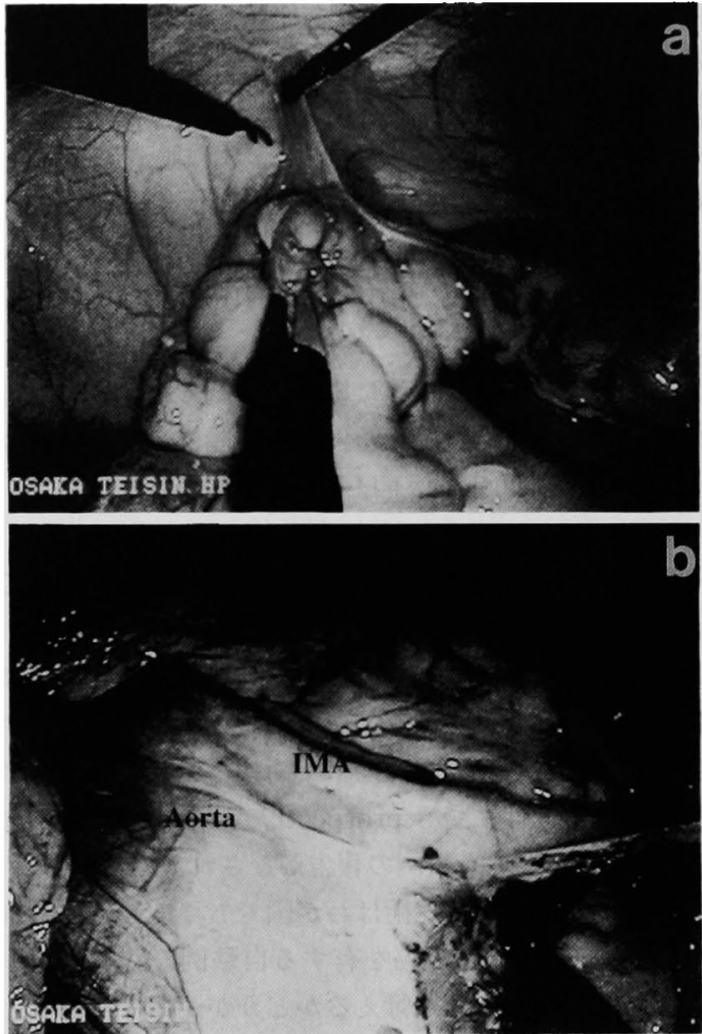

図 $3 a$ : 腹腔鏡下に右側結腸を腹壁および後腹膜よ り剩離す. $\mathbf{b}$ ：腹腔鏡下に下腸間膜動脈根部を露出 す.

INIA : inferior mesenteric artery

行った。

大腸全摘後の再建法は当初回腸瘦作製術として行わ れたが，1960年代には直腸肛門機能を温存する回腸直 腸吻合術が Aylet ら ${ }^{6}$ により報告された。1980年には

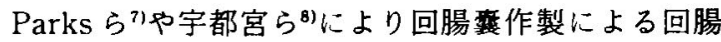
票肛門吻合が報告され，これらが現在標準術式となっ ている．現在では再建方法として，歯状線の肛門側粘 膜と回腸霊と吻合する (Ileal pouch anal anastomosis : IAA）方法と肛門管を温存し肛門管直上で回 腸䧶を吻合する (Ilealpouch anal canal anastomosis : IACA）方法があるが,この両者の違いは歯状線よりわ

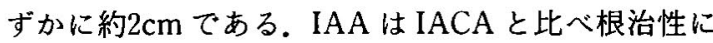
優れるが肛門機能を損なう可能性がある.FAPに対し ては，その根治性からIAAを選択する施設もある が9，両者に長所短所がある以上十分なインフォーム ドコンセントによる術式選択が必要と考えられる，今 回われわれは吻合法としてIACA を選択したが、腹腔
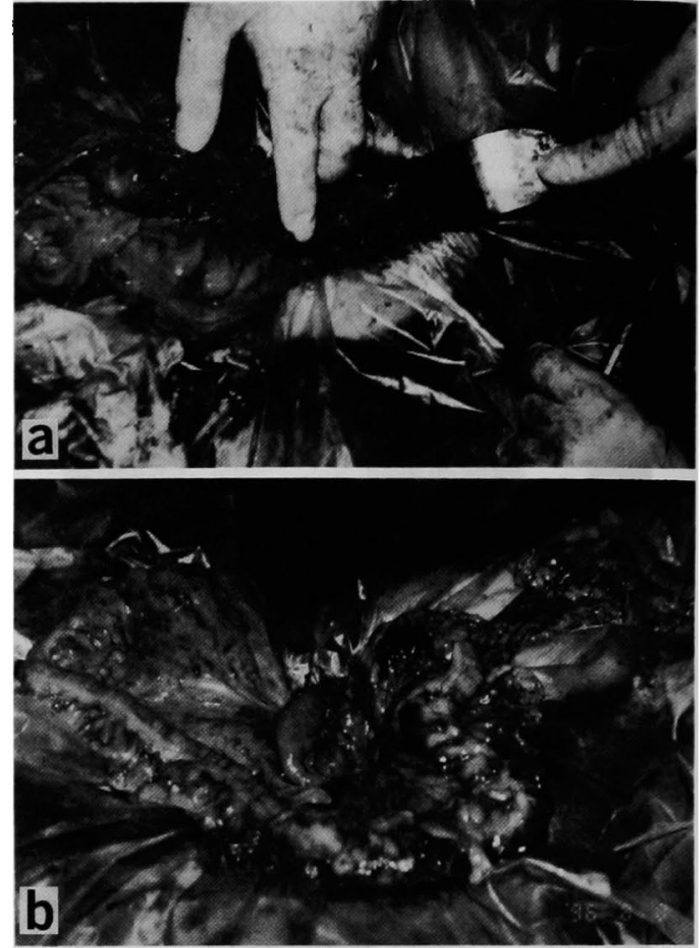

図 $4 a \mathrm{a}$ : 小切開創より下腸間膜動脈周囲リンパ節を 郭清す. b：小切開創より大腸全摘す。

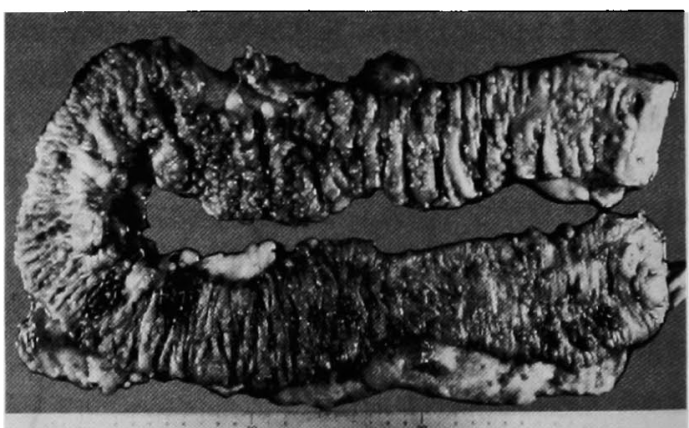

図 5 切除標本：全大腸に無数の腺腫を認めS 状結 腸に $33 \times 38 \times 15 \mathrm{~mm}$ の Borrmann 1 型腫瘍を認め た.

鏡補助下大腸全摘術において小切開が小さくすむ吻合

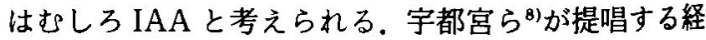
肛門的肛門管粘膜剝離法をかなり直腸上部まで進めれ ば腹腔鏡下での剥離が難しいとされる肛門管部分の剝 離ができ更なる低侵襲手術が可能となる。

FAP は疾㭧の性格上血縁者が罹患者である場合が 
あり血縁者に対しても手術に対する恐怖を与えること があってはならないと考える．今後も本疾患に対する 安全かつ低侵贅な術式の開発が望まれる。

\section{結 語}

進行結腸癌を伴う FAP に対し腹腔鏡補助下大腸全 摘術を施行し良好な結果を得たので若干の文献的考察 を加え報告した。

本論文の要旨は, 第160回近掝外科学会にて発表した. 文献

1) Jocobs M, Verdeja JC, Goldstein HS : Minimally invasive colon resection (laparoscopic colectomy). Surg Laparosc Endosc $1: 144$ $-150,1991$

2) Wexner SD, Johansen OB, Nogueras JJ : Laparoscopic total abdominal colectomy. A prospective trial. Dis Colon Rectum 35: 651644, 1996

3）仲野 明, 嶋田 紘, 福島恒男：腹腔鏡下手術, 腹 胫鏡補助下の大陽全摘術. 手術 $48 ： 868-872$,
1994

4）宮島伸宜, 大滝修司, 加納宣康：当科に扔ける腸疾 患に対する腹腔鏡下手術の適応と手技. 日本大腸 肛門病会誌 $48: 639-644,1995$

5）渡辺昌彦, 大上正裕, 寺本龍生：現時点で進行癌は 適応となりうるか. JSES 1:24-30, 1996

6) Aylett SO: Three hundred cases of ulcerative colitis treated by totalcolectomy and ileorectal anastomosis. Br J Surg 23 : 1001-1005, 1963

7) Parks AG, Nicholls RJ, Belliveau $P$ : Proctocolectomy with ileal reservoir and anal anastomosis. Br J Surg 67 : 523-538, 1980

8) Utsunommia $J$, Iwata $T$, Imagjo $M$, et al : Total colectomy, mucosal proctectomy and ileoanal anastomosis. Dis Col Rectum $8: 459-$ 466,1980

9）福島恒男, 山本雅由, 鬼頭文彦：大腸全摘, 回腸衰 肛門吻合術と回腸变肛門管吻合術. 外科診療 31 : 789-795, 1996

\title{
LAPAROSCOPY-ASSISTED PROCTOCOLECTOMY FOR FAMILIAL ADENOMATOUS POLYPOSIS
}

\author{
Shuji TAKIGUCHI, Hirohide MARUYAMA**, Hiroshi YANO*, Mitsugu SEKIMOTO***, \\ Eiji TANIGUCHI, Shigeo MATSUI*, Yoshiaki NAKANO*, \\ Hideo TATEISHI*, Masakatsu KINUTA*, Takushi MONDEN*, \\ Jun OKAMURA* and Shuichi OHASHI \\ Department of Endoscopic Surgery, Osaka University Medical School \\ *Department of Surgery, Osaka Teishin Hospital \\ **Department of Surgery, Osaka Rousai Hospital \\ ***Department of Surgery II, Osaka University Medical School
}

We report a case of familial adenomatous polyposis with an advanced cancer of the sigmoid colon which was treated with laparoscopic surgery.

A 36-year-old woman was pointed out to have a familial adenomatous polyposis with a signoid colon cancer by a barium contrast study of the colon. an operation was conducted through four $10-\mathrm{mm}$ trocars. the total colon was laparoscopically dissected and mobilized from the abdominal wall and retroperitoneum. the root of the inferior mesenteric artery was exposed. The total colon was extracted through a $9 \mathrm{~cm}$ lower abdominal midline incision. The gastrocolic ligament and right side of the mesocolon were incised. Lymph node dissection of the inferior mesenteric artery was perfromed through the incision. The lower recutm was dissectd through the incision. the total colon was removed through the incision after transcetion of the rectum and ileum. Ileal-reservoir (J-pouch9 and anal anastomosis were performed. The operation time was 6 hours and 34 minutes. Postoperative course was uneventful. As three months after the surgery, anal function has been good and the patients has bowel movements 3 or 4 times a day. 